\title{
Federal Withholding on Employee Fringe Benefits for Income and Social Security Taxes
}

One of the most vexing problem areas in the field of federal taxation is the tax treatment of employee fringe benefits. The magnitude of these benefits makes the issue particularly important. Not only do fringe benefits constitute a significant proportion of the national payroll, ${ }^{1}$ but also in many cases they comprise a substantial proportion of an employee's compensation. ${ }^{2}$ The endless array of factual situations in which employees receive fringe benefits and the bewildering variety of benefits offered ${ }^{3}$ make their proper tax treatment an exceedingly difficult issue, as reflected in the large volume of literature devoted to this subject. ${ }^{4}$

At the outset, two fringe benefit issues must be distimguished. The question of the extent to which fringe benefits should be taxed as income has proved to be a particularly intractable problem that has attracted much recent attention from commentators as well as from the Treasury Department itself. 5 This Comment, however, focuses on a different topic-the question of to what extent fringe benefits are subject to withholding for federal taxes. Both imcome tax and social security tax laws ${ }^{6}$ require employers to withhold a percentage of "wages." This Comment will address the issue of which fringe benefits constitute

1. See Weisman, $A$ Model For the Equitable Taxation of Fringe Benefits, 56 Taxes 347, 349 (1978); Note, Taxation of Fringe Bentefits: Alternative Approaches to Current Problems, 13 SuFFOLK U.L. REV. 1430, 1430 n.3 (1979).

2. See, e.g., Rowan Cos. v. United States, 624 F.2d 701 (5th Cir. 1980), rev'd, 101 S. Ct. 2288 (1981); Pacific Am. Fisheries, Inc. v. United States, 138 F.2d 464, 465 (9th Cir. 1943).

3. Cases discussed in this Comment involve meals, lodging, moving expenses, and conventious. Other popular fringe benefits include company cars, club dues and memberships, busincss entertaimment and tickets, air travel, and interest-free loans. See Mann, Black, White and Gray Fringe Benefits-Is Employer Withholding the Key to Rational Taxation?, 31 U.S. CAL. L. CENTER TAX Inst. 421, 435-41 (1979).

4. See, e.g., id; Popkin, Taxation of Employee Fringe Benefits, 22 B.C.L. REv. 439 (1981); Wasserınan, Principles in Taxation of Nonstatutory Fringe Benefits, 32 TAx LAw. 137 (1978); Weisman, supra note 1; Note, Federal Income Taxation of Employee Fringe Benefits, 89 HARV. L. REV. 1141 (1976); Note, supra note 1.

5. Twice in the last five years the Treasury Department has published discussion drafts of fringe benefit regulations. See [1981] STAND. FED. TAX. REP. (CCH) $\mid 8991$ (text of draft discussion released on Jan. 15, 1981); 40 Fed. Reg. 41, 118 (1975) (Sept. 1975 draft discussion).

6. "Social security taxes" in this Comment refers both to Federal Insurance Contribution Act (FICA) taxes, I.R.C. $\$ \S 3101-3126$, and to Federal Unemployment Tax Act (FUTA) taxes, I.R.C. $\$ \S 3301-3311$. 
wages for withholding purposes. ${ }^{7}$

The United States Supreme Court has examined the issue of employer withholding on fringe benefits in two recent cases. In 1978, it held in Central Illinois Public Service Co. v. United States 8 that "wages" does not include all incoine received from employment. Thus, the Court concluded that the fact that a fringe benefit is taxable as income does not necessarily subject it to income tax withholding. Three years later, in Rowan Cos. v. United States ${ }^{9}$ the Court held that the scope of withholdimg is the same for social security and incoine tax purposes. It thus concluded that if a fringe benefit does not constitute incoine to the employee under the convenience of the eniployer doctrine, ${ }^{10}$ it is not subject to social security withholding. The Court, however, has never articulated an approach to be used to determine which fringe benefits constitute wages im the many situations im which the convenience of the employer doctrine does not apply. ${ }^{11}$ Consequently, to gauge their withholding obligations, employers inust often look to a large body of case law froin the lower federal courts.

This Comment analyzes the approaches used by the Supreme Court and the lower federal courts to define the scope of withholding and suggests an alternate test. Part I discusses the withholding statutes and the standards used by the Supreme Court and by the lower federal

7. This issue has also received a great deal of attention recently. In 1980 alone, the issue arose in the following cases: Rowan Cos. v. United States, 624 F.2d 701 (5th Cir. 1980), rev'd, 101 S. Ct. 2288 (1981); Oscar Mayer \& Co. v. United States, 623 F.2d 1223 (7th Cir. 1980); Beau Rivage Restaurant, Inc. v. United States, 80-2 U.S. Tax Cas. I 9780 (S.D.N.Y. 1980); Hunuphrey Enterprises, Inc. v. United States, 80-1 U.S. Tax Cas. I 9377 (E.D. Wis. 1980); McGraw-Hill, Inc. v. United States, 623 F.2d 700 (Ct. Cl. 1980).

The Treasury Department has also shown great concern with the question. After failing to persuade the Supreme Court to hear Hotel Conquistador, Inc. v. United States, 597 F.2d 1348 (Ct. Cl. 1979), cert. denied, 444 U.S. 1032 (1980), which involved social security tax withholding on free meals furnished to employees, the Department promised to continue fighting similar social security tax cases in the courts. Rev. Rul. 80-41, 1980-1 C.B. 211. In early 1981, the Department issued guidelines specifying circumstances in which it would concede, suspend, or contest the issue of employers' withholding tax hability for fringe benefits in both the social security and imcome tax withholding contexts. 68 STAND. FED. TAX REP. (CCH), Tax Focus No. 2, at 3-4 (Feb. 25, 1980).

Several commentators have also grappled with the problem of fringe benefit withholding. See Kovey, Impact of Supreme Court Decision Limiting Witholding on Employees' Meal Allowances, 48 J. TAX. 276 (1978); Mann, supra note 3, at 445-48; Note, Are Nondeductible Meal Allowances Wages Subject to Withholding?, 29 BAYLOR L. REv. 145 (1977); Note, Withholding Tax on Wages: Central Illinois Public Service Co. v. United States, 29 ME. L. Rev. 401 (1978) [hereinafter cited as Maine Note]; Note, Employer Reimbursements Not Subject to F.I.C.A., F.U.T.A., and Income Tax Witholding, 10 WAKE FOREST U.L. REv. 651 (1974) [heremafter cited as Wake Forest Note].

8. 435 U.S. 21 (1978).

9. 101 S. Ct. 2288 (1981).

10. For a description of the convenience of the employer doctrine, see text accompanying notes 89-92 infra.

11. See note 35 and accompanying text infra. 
courts for determining whether fringe benefits are subject to withholding. It concludes that the courts have not yet developed a workable standard. Part II explores the legislative history of the Social Security Act and analyzes the Rowan decision. It concludes that the Court misinterpreted legislative intent when it concluded that Congress intended for incoine tax doctrines such as the convenience of the entployer rule to apply to social security withholding issues. Part III evaluates the Court's decision in Central Illinois and argues that, contrary to the Court's analysis, Congress did not intend for taxable fringe benefits to be excluded fron incoine tax withholding. Part IV recommends an approach that would subject all fringe benefits to withholding unless excluded for specific policy reasons articulated by Congress or the Treasury Departinent.

\section{I}

\section{The Definition of Wages}

\section{A. The Statutory Definitions}

Congress enacted the social security withholding tax provisions as part of the Social Seeurity Act of $1935,{ }^{12}$ which established a comprehensive systein of income security benefits. The Act contained two separate employment taxes to fund two different benefit programs. The Federal Insurance Contributions Act (FICA) tax ${ }^{13}$ funds old-age benefits. FICA requires withholding based on wages, ${ }^{14}$ which are defined as "all remuneration for employment, including the cash value of all remuneration paid in any medium other than cash." 15 The Federal Uneinployment Tax Act (FUTA) ${ }^{16}$ funds unemployment benefits. FUTA also imposes a withholding tax on einployees' wages, and it defines wages identically to FICA. ${ }^{17}$

Income tax withholding originated in the Revenue Act of $1942,{ }^{18}$ although the withholding provisions now in force were not adopted until a year later in the Current Tax Payment Act of 1943. ${ }^{19}$ As with the social security taxes, einployers inust withhold taxes based on employ-

12. Pub. L. No. 74-271, 49 Stat. 620.

13. FICA provisions are now codified in I.R.C. $\$ \$ 3101-3126$.

14. Id. \&3101.

15. Id. $\S 3121$ (a). Einployment is defined for FICA purposes as "any service, of whatever nature, performed by an employee for the person employing him." Id. \& 3121(b). The same definition applies to FUTA. Id. \&3306(c).

16. FUTA provisions are now codified at id. $\$ \S 3301-3311$.

17. Id. $\& 3306(\mathrm{~b})$.

18. Pub. L. No. $77-753, \& 172,56$ Stat. 884.

19. Pub. L. No. 78-68, 57 Stat. 126 (codified at I.R.C. $\$ \S 3401-3404$ ). The 1942 Act included a temporary "Victory Tax" that had a withholding provision. In 1943 Congress added a nearly identical withholding scleene to the income tax itself. 
ees' wages. ${ }^{20}$ Wages are defined as "all remuneration . . . for services performed by an employee for his employer, mcluding the cash value of all remuneration paid in any medium other than cash."21

The social security and income tax withholding provisions thus define wages in virtually identical terms. Indeed, while the courts have not always agreed on the scope of the definition, they have agreed that there is no significant difference in the statutes' verbiage. ${ }^{22}$

\section{B. Judicial Interpretations of the Statutory Definitions}

\section{Supreme Court Guidance}

The Supreme Court's two recent fringe benefit withholding cases-Central Illinois Public Service Co. v. United States ${ }^{23}$ and Rowan Cos. v. United States ${ }^{24}$ - provide only limited guidance in interpreting the scope of the statutory definitions of wages.

The unusual factual circumstances involved in the Court's 1978 Central Illinois decision make the case of limited value in determining in future cases what fringe benefits constitute wages. At issue in Central Illinois was whether cash allowances paid by an einployer for lunch expenses of certain employees constituted wages for withholding purposes. All parties agreed that the lunch allowances constituted income under the Court's decision in Commissioner v. Kowalski ${ }^{25}$ decided earlier the same term. They disagreed, however, about whether the employer should be lield liable for a deficit for failing to withhold incoine taxes on lunch allowances paid in 1963, fifteen years before Kowalski was decided. Citing the lack of clarity im the regulations in 1963 as to the obligation to withhold on such payments, ${ }^{26}$ and obviously concerned about the issue of retroactivity im requirmg withholding when it was not even settled until 1978 that the allowances constituted incoine, ${ }^{27}$ the Court declined to equate wages with imcome for withholding purposes. ${ }^{28}$ However, the Court did not articulate a principle for decidimg which fringe benefits constitute wages in future cases where

20. I.R.C. $\S 3402$.

21. Id. \& 3401(a).

22. E.g., Rowan Cos. v. United States, 101 S. Ct. 2288, 2294 (1981).

23. 435 U.S. 21 (1978).

24. 101 S. Ct. 2288 (1981).

25. 434 U.S. 77 (1977).

26. 435 U.S. at 32.

27. Id. at $25-26,32$ n.12.

After Central Illinois was decided, Congress itself acted to prevent the Kowalski decision from applying retroactively against employees. Act of Oct. 7, 1978, Pub. L. No. 95-427, § 3, 92 Stat. 996 (codified at I.R.C. \& 119).

28. The Court did not rely solely on the retroactivity rationale; it also interpreted the legislative history as showing a congressional intent to adopt a narrow definition of wages. For a discussion of this aspect of the Court's opinion, see text accompanying notes 118-19 infra. 
retroactivity and unclear regulations are not a problem. ${ }^{29}$ Indeed, the Court expressly left open the question of whether even these lunch allowances could be brought within the wages category under new regulations. ${ }^{30}$

The Court's decision im Rowan likewise provides little assistance in determining the scope of wages. The issue in Rowan was whether an employer had to withhold social security taxes on ineals and lodging it furnished to its employees while they were working on its offshore drilling rigs. The IRS conceded that under the convemence of the employer doctrine, ${ }^{31}$ these fringe benefits did not constitute incoine to the recipients. Thus, the employer concededly had no obligation to withhold income taxes. ${ }^{32}$ Nevertheless, relying on its regulations, ${ }^{33}$ the Service assessed the employer a deficiency for failing to withhold social security taxes. The Court held this was improper. Stressing the congressional concern with ease of administration reflected in the legislative history of the tax withholding schemes, the Court held that a uniform definition of wages slould be applied to the social security and incoine tax contexts and that the convemence of the employer doctrine should apply in both contexts. ${ }^{34}$ However, the Rowan Court did not otherwise atteinpt to define the scope of wages. Thus, in the inany cases that do not fall within the convemence of the einployer doc-

29. Courts and commentators have repeatedly found the retroactivity feature of Central IIIInois crucial to the opinion and argued that it weakens the impact of the remainder of the holding. See Rowan Cos. v. United States, 624 F.2d 701, 706 (5th Cir. 1980) (court noted that the regulations before it were prospective), rev'd, $101 \mathrm{~S}$. Ct. 2288 (1981); Goldsboro Christian Schools, lnc. v. United States, 79-1 U.S. Tax Cas. ๆ 9266, at 86,558 (E.D.N.C. 1978) (sanue); Kovey, supra note 7, at 276 (Court "undoubtedly influenced"' by the retroactivity problem); Mann, supra note 3, at 446 (retroactivity aspect may limit the future application of dccision in circumstances less favorable to taxpayer).

30. 435 U.S. at 32 n.12. In a concurring opimion, Justice Breunan stressed that new regulations would resolve the retroactivity problem. Id. at 33 (Brennan, J., concurring). Issumg new regulations might have clarified the fringe benefit withholding issue, but Congress preventcd this by imposing a freeze on fringe benefit regulations in October 1978, just eight months after the case was decided, that did not expire until May 31, 1981. See 68 STAND. Fed. TAX REP. (CCH), Tax Focus No. 2, at 1 (Feb. 25, 1981).

31. For a description of the convenience of the employer doctrine, see text accompanying notes $89-92$ infra.

32. $101 \mathrm{~S}$. Ct. at 2288 .

33. Treas. Reg. §31.3121(a)-1(f) (1956); Treas. Reg. §31.3306(b)-l(f) (1956) (FUTA). Both regulations provide that meals and lodging may be wages if they "constitute an appreciable part of the total reinuneration of . . . employees."

While the history of the regulations is an important issue in this area, it is beyond the scope of this Comment, Instead, this Comment will focus on the interpretation of the statutes theinselves and their legislative history in order to determine as nearly as possible what Congress intended when it originally enacted the withholding provisions. The question of how the IRS' regulations may have since affected that scheme is a separate inquiry and extremely complicated in itself. It is excluded from this discussion by practical considerations.

34. $101 \mathrm{~S}$. Ct. at 2294. For a more detailed discussion of the Court's legislative history analysis, see text accompanying notes 118-31 infra. 
trine, ${ }^{35}$ Rowan's only real guidance is its holding that wages are the same for incoine tax and social security withholding. Therefore, to determine whether specific fringe benefits are subject to withholding, courts must continue to refer to the tests developed by the lower federal courts.

\section{Lower Court Tests for Wages}

Although a few lower courts have considered the characteristics and purposes of the various withholding taxes, ${ }^{36}$ most have downplayed legislative history in their efforts to give meaning to the statutory definitions of wages. Instead, they have focused on the wording of the statutes and have tried to formulate objective tests that will indicate whether a certain benefit fits the statutory definition of wages. ${ }^{37}$ Given the nearly identical language in each of the statutes, this preoccupation with verbiage naturally resulted in courts applying the same tests whether mcome tax or social security taxes were involved even before Rowan established that the definitions are, in fact, congruent. Simce the core of all three definitions is the concept of "remuneration for services," ${ }^{38}$ it is that phrase which the courts have attempted to interpret. This section analyzes three tests the lower federal courts have suggested and argues that none of them provides a workable standard.

\section{a. Quid Pro Quo Test}

The concept of remuneration for services suggests the existence of an exchange: the employer provides some payment or remuneration in return for the employee's services. Several cases have focused on this exchange concept, applying a "quid pro quo" test. ${ }^{39}$

The seminal case is S.S. Kresge \& Co. v. United States, ${ }^{40}$ in which the employer, a department store, provided free lunches to lunch counter employees if they ate the meals in the store. The employer

35. Recent examples include Central Ill. Pub. Serv. Co. v. United States, 435 U.S. 21 (1978) (lunch reimburseinents); Oscar Mayer \& Co. v. United States, 623 F.2d 1223 (7th Cir. 1980) (personal use of company cars); Royster Co. v. United States, 479 F.2d 387 (4th Cir. 1973) (lunch reimbursenents); McGraw-Hill, Inc. v. United States, 623 F.2d 700 (Ct. Cl. 1980) (moving expenses).

36. See, e.g., Rowan Cos. v. United States, 624 F.2d 701, $706-07$ (5th Cir. 1980), rev'd, 101 S. Ct. 2288 (1981).

37. See, e.g., Royster Co. v. United States, 479 F.2d 387, 389-90 (4th Cir. 1973); Acacia Mut. Life Ins. Co. v. United States, 272 F. Supp. 188, 193-94 (D. Md. 1967).

38. See text accompanying notes 12-22 supra.

39. In addition to the cases discussed in this section, a number of other cases have applied or referred to the quid pro quo test. E.g., Hotel Conquistador, Inc. v. United States, 597 F.2d 1348, 1350 (Ct. Cl. 1979), cert. denied, 444 U.S. 1032 (1980); Beau Rivage Restaurant, Inc. v. United States, 80-2 U.S. Tax Cas. \ 9870, at 85,574 (S.D.N.Y. 1980).

40. 218 F. Supp. 240 (E.D. Mich. 1963). 
sued for a refund of FUTA and FICA taxes that the Service had assessed on the value of the free meals. The court found that the employer provided the meals for the purpose of having employees available in the event of a sudden rush of customers. Thus, the free meals "constituted the quid pro quo or remuneration for the half hour meal period that the employees made themselves available and for the services they possibly would perform."41 On this basis, the court held that the meals were wages for FICA and FUTA purposes. ${ }^{42}$

Under the quid pro quo test, if there is no exchange, the benefit does not constitute wages. This outcome is illustrated by Royster Co. $v$. United States, ${ }^{43}$ a case involving lunch reimbursements paid to salesmen who ate ineals while on the road. The court found that the salesmen were not on call during their lunch break and performed no services during that time. Applying the quid pro quo test, the court reasoned that the employer asked nothing in return for the meals; hence, there was no exchange. Therefore, the meals were not remuneration, and no withholding was required for either imcome tax or social security tax purposes. ${ }^{44}$

The quid pro quo test is fundamentally unsound. Employers do not ordinarily give money or other benefits to employees without expecting something in return. If an employer were to do so, the benefit would be a gift; ${ }^{45}$ but employers do not claim that fringe benefits constitute gifts. Thus, in every frimge benefit case, there is some exchange. Even in a case like Royster in which no particular perfornance is required of the employees, there is nonetheless an exchange. The benefit is in the nature of a bonus; it is given in return for the regular services of the employee, as a part of the total compensation package. ${ }^{46}$

The court in Campbell Sash Works, Inc. v. United States ${ }^{47}$ implicitly recognized that all fringe benefits involve exchanges. In Campbell the employer closed its plant for a short period and gave its employees

41. Id. at 244 (emphasis in original).

42. The court found it unnecessary to reach the question of whether the value of the meals would represent income under the convenience of the employer doctrine because it found the doctrine inapplicable to FICA and FUTA taxes, id. at 243; however, the court's opinion suggests that had the court reached the issue, it would have held that the meals constituted income, see id.

43. 479 F.2d 387 (4th Cir. 1973).

44. Id. at 391-92. The court did not decide whether the lunch allowances constituted incone to the employees; however, it is likely that they would constitute incone under Commissioner v. Kowalski, 434 U.S. 77 (1977).

45. See Commissioner v. Duberstein, 363 U.S. 278, 285 (1960).

46. See Humble Oil \& Ref. Co. v. United States, 442 F.2d 1362, 1370 (Ct. Cl. 1971) (Davis, J., dissenting in part).

47. 217 F. Supp. 74 (N.D. Ohio 1963). The Compbell opinion is written in an abbreviated memorandum fornat that makes the court's reasoning less than clear. While the court identified the crucial issues, it did not explicitly apply the language or approach of any of the tests discussed in this Comment. It is instructive primarily for its holding and the facts presented. 
an all-expense-paid vacation in Florida. The court found that the einployees performed no work or services durmg their trip. The employer simply gave the employees a vacation without requiring anything in return. Thus, using the analysis of Kresge and Royster, there would be no exchange and the value of the vacation would not be wages. Yet, the Campbell court held that the value of the vacation was wages for both income tax withholding and social security tax purposes. ${ }^{48}$ The court found that the employer's purpose in providing the vacations was to attract employees and lower employee turnover - the very reason that einployers pay weekly salaries and bonuses. Thus, regardless of the fact that the einployer did not explicitly require anything of its employees, there was a quid pro quo: the employer provided the vacation expecting a more stable work force. Indeed, for every benefit paid by an einployer to his einployees, there is some exchange. Therefore, the quid pro quo test cannot be a useful tool for determining which fringe benefits constitute wages.

\section{b. Employer Benefit Test}

While the quid pro quo test looks for an exchange, the einployer benefit test focuses on the term "remuneration." Its theory is that einployers make two types of payments to employees: payments that are intended to coinpensate employees for their services and payments that are intended to benefit the einployer. According to this test, only compensatory payinents are wages.

Peoples Life Insurance Co. v. United States ${ }^{49}$ was the first decision to apply the employer benefit test. In Peoples, the employer held annual conventions for its salesmen and paid their expenses. The IRS claimed that the conventions represented wages subject to income tax withholding. The court disagreed, noting that the conventions featured seminars, meetings, and other work-related activities. Also, the employer "expected" all invited salesmen to attend, and "[i]n practical effect, they were required to attend." 50 In short, the court concluded that the conventions were "important ingredients of [Peoples'] total corporate effort to build a stable, knowledgeable, and loyal agency force."51 The enployer provided the conventions for its own benefit and not to compensate einployees. Therefore, the court held that the payinents did not constitute wages.

The Peoples court atteinpted to distinguish Campbell. Although

48. Id. at 78. The court also held that the fair market value of the trips constituted income to the employees. I $I$.
49. 373 F.2d 924 (Ct. Cl. 1967) (per curiam).
50. Id. at 929 .
51. Id. 
the Peoples court recognized that the Campbell employer also wanted to mcrease the efficiency of his employees, it pointed out that the employer's primary purpose was to give the employees a vacation. Since each employee could take the trip or not as the employee wished and since no busmess was conducted on the trip, the Peoples court concluded that Campbell did not involve a payinent for the benefit of the employer. ${ }^{52}$

The employer benefit approach has been widely criticized by coinmentators. ${ }^{53}$ The key problem is that whenever an employer makes a payment to an employee, the employer receives a benefit, directly or imdirectly; indeed, $\mathrm{m}$ the usual case, both parties are benefited. ${ }^{54}$ That is the result of the ever-present exchange discussed above:55 the employer gives soine fringe benefit to the employee and receives some other benefit from the employee in return.

This argument can be illustrated by comparing the Peoples and Campbell cases. The Peoples court held that the payment of the convention expenses was not wages because the employer paid thein in order to build a stable sales force; the Campbell court found that payment of the vacation expenses was wages even though the employer provided the vacation in part to reduce employee turnover. The einployer in Peoples sought to make its employees more efficient by teaching them sales tcchniques; the employer in Campbell sought to improve its employees' efficiency by giving thein a rcst. A careful comparison of the two cases shows that the benefits to the employer were the same in both cases; only their methods of achieving them were different. ${ }^{56}$ Nevertheless, the Peoples court concluded that the cases should reach differing results under the employer benefit test. ${ }^{57}$

The employer benefit test completely inverts the logic of the quid pro quo test. This problem can be illustrated by again comparing Peo-

52. Id at 935 .

53. See Maine Note, supra note 7, at 412; Wake Forest Note, supra note 7, at 657-58. Nevertheless, a large number of cases have utilized the employer benefit test. See, e.g., Acacia Mut. Life Ins. Co. v. United States, 272 F. Supp. 188, 194-99 (D. Md. 1967); Hotel Conquistador, Ine. v. United States, 597 F.2d 1348, 1353 (Ct. Cl. 1979), cert. denied, 444 U.S. 1032 (1980); Humble Oil \& Ref. Co. v. United States, 442 F.2d 1362, 1367-69 (Ct. Cl. 1971).

54. Wake Forest Note, supra note 7, at 657-58.

55. See text accompanying notes $45-46$ supra.

56. It could be said that the enuployer benefit is direct in Peoples and indirect in Campbell, but the use of "directness" as a distinction is not supported by the statutes and no court has adopted it.

57. This is not to say that the outcome of Peoples was necessarily wrong, but only that the court's language and analysis were faulty. The court's opinion suggests that had the court addressed the question, it would have held that the convention expense payments did not constitute income to the employees. See 373 F.2d at 931-34. If this were true, under the approach suggested in this Comment, the payments would properly be excluded from nicome tax withholding requirements. See text accoinpanying notes I29, 134-38 infra. 
ples and Campbell. In Peoples, the employer required that its employees attend certain planned activities; in Campbell, the employer required nothing of the employees. Under the quid pro quo test, the fringe benefits in Peoples should be wages due to the exchange feature, while the Campbell benefits would not be wages since there was no exchange. However, applying the employer benefit test, the Peoples court held that the very fact that the employer required that the employees participate in certain activities as a condition of receiving the benefits dictated that the fringe benefits not be treated as wages.

This basic conflict in the logic of the employer benefit and quid pro quo tests is also apparent from a comparison of Humble Oil \& Refining Co. v. United States ${ }^{58}$ and Kresge. In Humble, the employer, a national corporation, often moved its employees from one office to another. When it asked employees to relocate, it reimbursed them for their moving expenses but did not withhold income taxes on those amounts. The IRS claimed that the reimbursements were wages for the purposes of mcoine tax withholding. The court applied the employer benefit test and examined the motives of the employer in providing the reimbursements. It found that the employer paid the benefits as "an inducement to [the employees] to make the requested inove."59 Thus, the court concluded that the employer provided the reimbursements for its own business purposes and its own benefit. Under the employer benefit test the reimbursements were not compensatory and were not wages. ${ }^{60}$

In Kresge, however, the court applied the quid pro quo test instead and came to the opposite conclusion despite the similarity of the cases. In Kresge, the employer provided free meals in order to have extra help available at lunch time. Under the quid pro quo test, because the employer provided the ineals in return for the employee's service, the meals were remuneration and thus taxable wages. Yet im both Kresge and Humble the employer gave the benefit in order to have employees available for work at a certain place and in both cases the employer received a benefit froin the availability of the employees.

Because the logic of the employer benefit test is simply an inversion of the quid pro quo test, the result in an individual case will usually turn on which test the court applies. Moreover, correctly viewed, every fringe benefit case imvolves a quid pro quo, a benefit for the employer, and a benefit for the einployee. Consequently, neither the quid

58. 442 F.2d 1362 (Ct. Cl. 1971) (per curiam).

59. Id. at 1368.

60. The court reached this conclusion even though it conceded that the moving expense reimbursennents constituted income to the employees under Ritter v. United States, 393 F.2d 823 (Ct. Cl.), cert. denied, 393 U.S. 844 (1968). 442 F.2d at 1365-66. 
pro quo test nor the employer benefit test can provide useful guidance in determining whether a given fringe benefit constitutes wages.

\section{c. Services Test}

The final test focuses on the "services" component of the "remuneration for services" definition. It assumes that some fringe benefits are given in return for services by the employee and some are given in return for soinething that does not constitute services. Under this test, fringe benefits fall within the definition of wages only when they are received in return for services.

Although no court has explicitly applied this test, several have recognized it by implication. In Humble, the court noted that "[n]o service was performed by plaintiff's employees in order to obtain these reimburseinents, unless it be the act of physically inoving froin one permanent job location to another at plaimtiff's request . . . ."61 Although, as explained above, the court eventually rested its decision that the moving expense reimburseinents were not wages on an einployer benefit analysis, ${ }^{62}$ it is nevertheless apparent that the court did not accept relocating as a service by the employees. ${ }^{63}$ Consequently, the reimbursements could not be remunerations for services.

More recently, in Hotel Conquistador, Inc. v. United States, ${ }^{64}$ the court seemed to rely in part on the services test. In that case, the einployer hotel provided meals in a special employees' cafeteria for many of its employees. The court found that the einployer provided the ineals primarily to minimize the length of employee meal breaks by eliminating the need for employees to change out of uniforms or to leave the premises. In determining that the ineals were not taxable for social security tax purposes, the court noted that the employees performed no services while on their ineal breaks. Moreover, eating in the cafeteria could not be a service for which the ineals were coinpensation: "If the $\$ 1.25$ value [of the meals] is regarded as compensation for being in the cafeteria for 30 or 45 minutes (and not elsewhere) inquiry would be necessary whether the applicable minimuin wage was respected."65 The court refused to characterize "not leaving the building" as a

61. 442 F.2d at 1365 .

62. See text accompanying notes 58-60 supra.

63. This may explain the different outcoines in Kresge and Humble. In Kresge, the court saw the ineals as compensation for the employees making "themselves available and for the services they possibly would perform." 218 F. Supp. at 244 (emphasis added). In Humble, it was clear that the relocating employees would receive a salary for the services they performed at the new location. Thus, the reimburseinent must be in return for the relocation itself, which the court was loath to characterize as a service.

64. 597 F.2d 1348 (Ct. Cl. 1979), cert. denied, 444 U.S. 1032 (1980).

65. Id at 1352 . 
service. ${ }^{66}$

The services test has at least two problems. The first problem is the difficulty of determining which acts constitute services. "Services" is not defined in the withholding tax statutes, and no court has examined the legislative history to ascertain what Congress meant by the term. "Services" generally means the performance of labor for the benefit of another. ${ }^{67}$ In all fringe benefit cases, however, the performance by the employee-whether it be moving across the country or eating on the road-is for the benefit of the employer. But an employee's particular act is not always the type of service for which the employee is generally paid. For example, the insurance salesmen in Peoples had their convention expenses paid not in return for selling insurance but for attending meetimgs. ${ }^{68}$ Without an understanding of the legislative intent, there can be no principled way of dividing these employee actions into service and nonservice activities.

A second problein with the services test, as well as with both the quid pro quo and the einployer benefit tests, is that they all require a case-by-case examination of the circumstances in which the frimge benefits are received. Due to the endlessly varying factual contexts in which frimge benefit issues arise, these tests all entail burdensome administrative expenses and uncertainty which are damaging to the federal tax system. ${ }^{69}$

In sum, none of the three current judicial tests provides a workable standard for determining what frimge benefits constitute wages. To develop effective rules the courts should closely examine the legislative history of the applicable statutes-a task this Comment undertakes in Parts II and III.

II

THE SCOPE OF WithHOLDING FOR SOCIAL SECURITY TAXES

The purpose of this part is to examine carefully the legislative history of the social security tax provisions and to evaluate whether the

66. One commentator has argued that Royster also applied the services test. Wake Forest Note, supra note 7. The Royster court reasoned that, although the salesmen "performed no services" during their lunch breaks, they did benefit the employer indirectly by traveling less mileage than if they went home to eat. 479 F.2d at 390-91. The commentator argues: "the question presented was whether this benefit constituted a 'service' to the employer within the meaning of the statutes. The court concluded, without stating its reasoning, that under these facts the reimbursements were not for services performed." Wake Forest Note, supra note 7, at 654. By implication, the court lield that "not going home for lunch" was not a service.

67. Faul v. Commissioner, 263 F.2d 645, 649 (9th Cir. 1959) (quoting Webster's INTERNATIONAL Dictionary (2d ed.)).

68. See text accompanying note 50 supra.

69. See text accompanying notes $132-33$ infra. 
Supreme Court's holding in Rowan Cos. $v$. United States, ${ }^{70}$ that income tax doctrines can be used to resolve social security withholding issues, is consistent with that legislative history.

\section{A. Legislative History}

The Social Security Act of $1935^{71}$ marks a turning point in United States income security pohcy. ${ }^{72}$ Against a background of legislative inaction in the income security area, the Depression provided a strong catalyst for the Social Security Act. Faced with the worst unemployinent in United States history, widespread poverty, and the exhaustion of private charities, President Roosevelt forined the Committee on Economic Security to suggest legislative action. ${ }^{73}$ The Committee saw unemployment as the key threat to income security in America and perceived old-age dependence as a particularly difficult facet of the unemployment problem. ${ }^{74}$

With the focus on unemployment and old age, it was inevitable that the Social Security Act would be directed toward workers. Only workers are subject to unemployment. Moreover, ouly workers' economic security is threatened by old age; those who live on interest or investment income do not face income interruption due to advancing age. $^{75}$

Congress' choice of funding inethods was responsive both to the fact that the primary beneficiaries of the Social Security Act would be workers and to the political climate of the day. In 1935, welfare was politically unpopular in the United States. The proponents of social security, particularly President Roosevelt, felt strongly that a program of transfers to the needy had little chance of passage and dim prospects for ever receiving adequate funding. ${ }^{76}$ The solution to this problem was to fund the prograin not through general revenues, but through contributions by the very workers who would receive benefits. ${ }^{77}$ The

\footnotetext{
70. 101 S. Ct. 2288 (1981).

71. Pub. L. No. 74-271, 49 Stat. 620.

72. [F]ederal legislation in the area of income security was practically nonexistent before 1934, and federal concern with the area was miniscule. And im the states that had developed some philosophy in this area, the vast inajority had not considered income security-or indeed almost any act of social welfare-as a legitimate responsibility of government.

Statutory History of the UnIted States: Income Security 59 (R. Stevens ed. 1970).

73. Id.

74. See id. at 64-69.

75. See Joyce v. Mathews, 569 F.2d 1039, 1041 (8th Cir. 1978) (per curiam); Delno v, Celebrezze, 347 F.2d 159, $161 \&$ n.2 (9th Cir. 1965).

76. See M. Derthick, Policymaking for Social Security 229-30 (1979).

77. Years later, Roosevelt commented on the choice of funding:

[It was] politics all the way through. We put those payroll contributions there so as to give the contributors a legal, noral, and political right to collect their pensions and their
} 
use of payroll taxes enabled proponents to characterize social security as an insurance program rather than as a welfare program. ${ }^{78}$

The contributory insurance model thus links the receipt of benefits to prior wage earning. In order "to assure that only workers with reasonably firm attachment to the labor force qualify for benefits," employee must have worked a minimum number of weeks to be eligible for unemployment benefits. ${ }^{80}$ Likewise, to receive retirement benefits, individuals must have earned taxable wages. ${ }^{81}$

This link between benefits and wages has been strictly enforced by the courts. In Joyce v. Mathews, ${ }^{82}$ for example, a couple claimed oldage benefits under the Social Security Act. The claimants had accumulated enough quarters of coverage to qualify, but in some of the quarters their only income was froin a closely-held corporation of which they were the sole stockholders. The corporation owned and operated rental properties, and the evidence showed that the claimants performed soine services for the corporation. The court ruled against the claimants, however, finding their services to be minimal. In effect, the court stated, the claimants held investment properties and had merely simnlated an employment relationship in an attempt to qualify for social security benefits. The court relied on Delno v. Celebrezze, ${ }^{83}$ which had stated the rule concisely: "entitlement to benefits is based upon the receipt of income froin labor, which old age, death, or disability would interrupt; and not upon the receipt of income from the investment of capital, which these events would presumably not affect." 84

The link between taxes and benefits is crucial in determining whether frimge benefits should be considered taxable wages. Social security benefits are designed to protect employees whose income is subject to imterruption due to old age or unemployment. In adopting an

unemployment benefits. With those taxes in there, no damn politician can ever scrap my social security program.

A. Schlesinger, JR., The Age of Roosevelt: The Coming of the New Deal 308-09 (1958) (footnote omitted). Decades later, President Reagan has learned the truth of that statement. See, eg., Cuts in Social Security?, NewswEek, Sept. 21, 1981, at 40.

78. See J. Brittain, The Payroll Tax for Social Security 6-9 (1972); M. Derthick, supra note 76, at 230-31; P. FerRarA, Social SECURITY: THE INHERENT CONTRADICTION 16-17, 20-22 (1980).

79. National Commission on Unemployment Compensation, Unemployment ComPENSATION: FINAL REPORT 15 (1980).

80. The states operate unemployment insurance programs under federal supervision. See I.R.C. $\$ \S 3302-3305$. Each state plan links the receipt of unemployment benefits to prior earning of taxable wages. See P. FerRara, supra note 78, at 32-36; NAtional Commission on UNEMPLOYMENT COMPENSATION, supra note 79, at 15-16.

81. See M. DeRTHICK, supra note 76, at 214-15; P. FerRARA, supra note 78, at 36-38.

82. 569 F.2d 1039 (8th Cir. 1978) (per curiam).

83. 347 F.2d 159 (9th Cir. 1965).

84. Id. at 161 (footnote omitted). 
insurance-type system, Congress chose to tax employees on the employment benefits they would lose if unemployed. If einployment is interrupted, employees lose not only their salary but also all fringe benefits. Therefore, under the insurance scheme, the tax base statutorily designated as "wages" should include all fringe benefits as well as salary.

The foregoing analysis also explains why Congress did not attempt to include all einployee income within the social security tax base. Many einployees receive an hourly wage or weekly salary plus certain fringe benefits. They may also own stocks, bonds, and other investments. If their employment is interrupted, they will lose their salary or hourly wage and all fringe benefits, but their investment imcome will be undisturbed. Consequently, under the social security system's insurance scheme, it would be inappropriate to tax the investinent imcome since it is not subject to loss through unemployment.

In the only pre-Rowan Supreme Court case raising the issue of the proper scope of the social security tax base, the Court applied a standard that would seem to bring all fringe benefits into the social security system. Social Security Board v. Nierotko ${ }^{85}$ involved a plaintiff who had been wrongfully discharged by his employer and who was reinstated by the National Labor Relations Board and awarded a sum of money for the "back pay" he had lost after his ternination. The plaintiff sought to have the backpay award credited to his Old Age and Survivor's Insurance account. The Social Security Board argued that the plaintiff had performed no services during his absence and that benefits had to be "related to 'wages earned' for 'work done.' "86 The Supreine Court rejected such an interpretation, finding that Congress meant services to include "not only work actually done but the entire employer-employee relationship for which compensation is paid to the employee by the employer." ${ }^{\text {877 }}$ The Court accordingly concluded that the award of backpay constituted wages and ordered the amount credited. By the Court's standard, all fringe benefits that fall within "the entire employer-employee relationship" should be taxable for social security purposes. ${ }^{88}$

\section{B. The Rowan Court's Analysis}

If, as just discussed, Congress imtended the tern "wages" in the

85. 327 U.S. 358 (1946).

86. Id at 365 (footnote omitted).

87. Id. at 365-66 (footnote omitted).

88. While subsequent cases, including the Supreme Court's Rowan decision, have departed froin the Nierotko standard, none has offered a convincing alternative interpretation of the legislative intent. For a critical evaluation of the Rowan Court's legislative history analysis, see text accompanying notes 104-10 infra. 
social security withholding provisions to include all benefits accruing from employinent, the cases discussed in Part I that sought to establish two categories of benefits, one subject to social security withholding and one not, were incorrectly decided. This section argues that the Rowan Court compounded this error by applying tle convernence of the einployer doctrine - an incoine tax doctrine-to resolve a social security withholding issue.

The convenience of the employer doctrine is a doctrine of income taxation that holds that certain meals and lodging provided by an employer for its own purposes will not be taxed as income to the recipient employees. ${ }^{89}$ Origmally developed as a common law doctrine, ${ }^{90}$ the rule was codified in $1954 .{ }^{91}$ The theory underlying the doctrine is that when an employer provides such benefits for its own convenience, it often conditions and limits the benefits in such a way as to reduce substantially their value to the einployee. For example, when the employer requires einployees to eat their free meals at the place of employment, the value to the employee may be significantly less than the market value of the meals miglit indicate. As a result, even tlough the fringe benefits theoretically constitute inconie in the sense that they represent accretions to wealth, ${ }^{92}$ to avoid the difficulty of determining the actual value to the employees, the benefits are excluded from gross income and are not taxed.

In order to evaluate the soundness of the Rowan Court's decision that the convenience of the employer doctrine could be used to determime what fringe benefits are subject to social security withholding, it is first necessary to examme the case in greater detail. As discussed in Part I, the issue in Rowan was whether the value of meals and lodging provided to Rowan employees was subject to social security withholding even though it was excluded from income under the convenience of the employer doctrine. ${ }^{93}$ In suing for a refund of FICA and FUTA taxes it had paid under protest, the employer claimed that "wages" has the same ineaning for imcome tax and social security purposes. Tlius, the employer reasoned, the IRS could not tax fringe benefits for social security purposes if they were not subject to income taxation.

89. See Kragen \& Speer, I.R.C. Section 119: Is Convenience of the Employer a Valid Concept?, 29 HASTINGS L.J. 921 (1978).

90. For a discussion of the common law development of the doctrine, see Commissioner v. Kowalski, 434 U.S. 77, 84 (1977).

91. I.R.C. \& 119.

92. The accretion to wealth definition of income, also known as the "Haig-Simons" definition, is a well-known economic theory of income. Although its theoretical soundness is widely accepted, it is generally agreed that it would be administratively impossible to use the definition for taxation purposes. See Mann, supra note 3, at 422-23.

93. See text accompanying notes 31-35 supra. 
The Rowan court of appeals disagreed. The court held that although the statutes defining wages use equivalent language, their actual scope must be determined by examining "the purposes of the statutes, the uses made of their revenues and their relationship with other statutes." 94 The court found two major differences between income and social security taxes. First, mcome tax withholding is a means of collectimg a tax used for general expenditures, while the social security taxes raise revenues that are intended primarily for the benefit of the employees theinselves. Second, the einployer's liability is primary in the social security tax case and secondary in the income tax case; that is, only for income tax purposes is the employee liable if the einployer fails to withhold taxes. In view of these differences, the court held that the IRS's differing interpretations of the statutes were reasonable and should be upheld. ${ }^{95}$

The court also recognized the need for ease of administration of the tax withholding scheme. It concluded, however, that requiring employers to use two different standards in computing their withholding tax liability would not be unduly burdensone in light of modern business practices. The court pointed out that simce most busmesses use computers to calculate withholding taxes, it would be a "simple inatter to devise a program that includes some items for one or two taxes and excludes the same iteins in calculating others." 96 Having thus determined that it was unnecessary to use identical bases for income tax and social security withholding, the court of appeals did not reach the question of whether it would ever be appropriate to use the convenience of the employer doctrine in the social security context.

In reversing the court of appeals, the Supreme Court stressed congressional concern with ease of administration. According to the Court, Congress sought to ensure simplicity and efficiency by using the same base for social security and income tax withholding. The Court pointed out that when the withholding schene was adopted for incoine tax purposes, Congress rejected a proposal that would liave withheld income taxes on dividends and bond interest as well as wages. The statute finally passed required withholding only upon wages, the same withholding base already used for social security withholding. The Court interpreted this action to inean that Congress intended that the tax bases be identical for social security and income tax withholding. The Court also found evidence of this intent im a committee report

94. 624 F.2d at 706.

95. The court also relied on its finding that regulations requiring withholding on these benefits for FICA and FUTA purposes had been consistently in effect for 40 years. Id. at 702 . In contrast, the Supreine Court subsequently found the history of IRS regulations on this subject to be "far from consistent" $101 \mathrm{~S}$. Ct. at 2295. See notes 33-34 and accoinpanying text supra.

96. 624 F.2d at 706-07. 
which noted that certain statutory exceptions to wages for incone tax withholding are "identical with the exceptions extended to such services for Social Security tax purposes and are intended to receive the saine construction and have the same scope." 997 According to the Supreme Court, then, the court of appeals was not entitled to judge whether having two separate definitions of wages would be a burden on administration of the tax system. Congress had already determined that simphicity would be best achieved by using a uniform definition of wages. ${ }^{98}$

The Court next examined whether the convenience of the einployer doctrine could be applied to resolve social security tax issues. The government argued that social security taxes were designed for a different purpose than the income tax and were intended to tax a very broad range of employee benefits without reference to income tax doctrines. The Court disagreed. It found that broad references to "rooin, board etc." as wages in the Social Security Act committee reports ${ }^{99}$ were "ambiguous" and did not prove that Congress ineant "to tax remuneration in kind without regard to principles developed under income taxation, such as the convenience-of-the-employer rule." 100 The Court found no proof that Congress "intended to exclude this estabhished rule" from the social security tax area. ${ }^{101}$ Therefore, the Court held that the social security tax provisions are subject to the convenience of the employer exclusion and that the Treasury regulations to the contrary were invalid.

As will be shown in Part III, the Rowan Court's conclusion that Congress intended to track the social security definition of wages when it adopted the income tax withholding provisions in 1942 is generally

97. 101 S. Ct. at 2294 (quoting S. REp. No. 1631, 77th Cong., 2d Sess. 166 (1942)). The exceptions to which the Report referred did not exempt any fringe benefits from withholding. Rather, they excluded remuneration paid for agricultural labor, domestic services, and casual labor not within the employer's trade or business. As the Report explained, these exceptions were designed to "relieve farmers, housewives, and others from the burden of collecting and accounting for small amounts of tax." Id.

98. Prior to Rowan, the federal courts were sharply dividcd on the question of whether "wages" had the same meaning for both types of withholding taxes. Cases holding that wages should have the same scope for income tax and social security withholding included Oscar Mayer \& Co. v. United States, 623 F.2d 1223, 1228 (7th Cir. 1980); Royster Co. v. United States, 479 F.2d 387 (4th Cir. 1973); Hunphrey Enterprises, Inc. v. United States, 80-1 U.S. Tax Cas. I 9377, at 84,002 (E.D. Wis. 1980); and Hotel Conquistador, Inc. v. United States, 597 F.2d 1348, 1351 (Ct. Cl. 1979), cert. denied, 444 U.S. 1032 (1980). Cases reaching the opposite conclusion included Rowan Cos. v. United States, 624 F.2d 701 (5th Cir. 1980), rev'd, 101 S. Ct. 2288 (1981); Bcau Rivage Restaurant, Inc. v. United States, 80-2 U.S. Tax Cas. I 9780, at 85,574 (S.D.N.Y. 1980); and Goldsboro Christian Schools, Inc. v. United States, 79-1 U.S. Tax Cas. I 9266, at 86,558-59 (E.D.N.C. 1978).

99. E.g., H.R. REP. No. 615, 74th Cong., 1st Sess. 32 (1935).

100. $101 \mathrm{~S}$. Ct. at 2295.

101. Id. 
consistent with the legislative history of the income tax withholding provisions. ${ }^{102}$ However, incoine tax withholding features a major qualification that introduced an asymmetry into the definitions: only benefits that will eventually be subject to imcone taxation can logically be subject to mcome tax withholding. ${ }^{103}$ However, this qualification should not influence our reading of the Social Security Act of 1935.

The Rowan Court pointed to no affirmative evidence that Congress meant the convenience of the einployer doctrine or any other income tax doctrine to apply to social security taxes. Instead, it based its holding on a negative inference: since the legislative history showed no intent to exclude mcome tax principles, then those principles must apply to the social security tax. This reasoning has several flaws.

First, the Court was wrong to draw so heavily on the legislative history of the mcome tax withholding provisions im interpreting the Social Security Act. The concept of wages was developed first im the social security context in 1935 , seven years prior to the enactınent of the mcome tax withholding provisions. ${ }^{104}$ In imterpreting its meaning the Court should thus have looked first to the circumstances that existed in 1935. In view of Congress' silence with respect to the use of incoine tax doctrines, its deliberate refusal to use general incoine tax revenues to fund social security suggests that the social security tax and the concept of wages were bemg newly developed and were not to be interpreted by using income tax doctrines.

Second, the Court failed to recognize that due to the fundainental differences in the purposes of social security and incoine taxes, Congress targeted different tax bases. ${ }^{105}$ To generate revenues to fund the general costs of the federal government, Congress chose to tax income. In contrast, the focus of social security is einploynent. ${ }^{106}$ It is the receipt of benefits within the einploynent relationship that entitles a worker to social security payments and, conversely, subjects him to taxes. Given this essential difference in the tax base selected by Congress, the Rowan Court erred in automatically applying incoine tax principles to social security absent specific evidence that Congress intended that those principles apply.

102. See text accoinpanying notes $120-28$ infra.

103. See text accoinpanying notes $129-31$ infra.

104. See text accompanying notes 71-81 supra and notes 120-27 infra.

105. The court of appeals held that the purposes of the two taxes were different. $624 \mathrm{~F} .2 \mathrm{~d}$ at 706. However, that court did not examine the bases of the two taxes, which is the detcrmining factor. If Congress had enacted two identical mcome taxes at different times and used the revenues for different purposes, that fact alone would not justify a court in imterpreting the taxes' scopes differently. Here, however, the two taxes were not meant to reach the same funds and must be treated separately.

106. Indeed, social security taxes are often called "employinent taxes." 
Third, the convenience of the employer doctrine is incompatible with social security principles. As explained above, the convemience of the employer doctrine excludes some fringe benefits from inconie taxation because of the difficulty of measuring the increase im an en1ployee's wealth when he receives benefits subject to employer restrictions. ${ }^{107}$ This rationale, however, does not apply to social security, where the focus is not on the exact amount of benefit to the enployee but rather on the employment relationship. If an appreciable portion of an employee's renuneration is received in the forin of fringe benefits, those benefits represent a substantial source of support that is subject to interruption by old age or unemployment. If the employment relationship is interrupted, the eniployee loses those fringe benefits. Benefits that derive from the employment relationship are precisely the sort of payment that qualifies a worker for social security benefits. Under the insurance rationale, they should equally give rise to an obligation to contribute.

Fimally, even if one accepts the Court's arguinent that im enacting the social security withholdimg system Congress imtended to incorporate the convenience of the employer doctrine, Congress inust liave intended to use the doctrine as it was understood im 1935. In the years simce then, the doctrine lias undergone inany judicial remterpretations and changes. ${ }^{108}$ All of the courts were dealing with incoine tax questions when they analyzed and nodified the doctrine; until Rowan no court utilized the doctrine in the social security context. In addition, in 1954 Congress codified the doctrine im the income tax provisions of the Internal Revenue Code ${ }^{109}$ but did not expressly mcorporate it into social security taxes or otherwise suggest that it applied outside the imcome tax context. Therefore, it would seem that if the social security taxes were intended to utilize the doctrine at all, it must be in its 1935 form. Nonetheless, the Supreme Court held im Rowan that the congressional action in codifying the doctrine did not foreclose the application of the doctrine to other taxes. ${ }^{110}$ The Court lield that despite judicial and legislative development of the doctrine since 1935, the social security taxes incorporate the current forn of the convenience of the einployer doctrine.

In summary, the Rowan Court's reliance on income tax principles led to a faulty definition of wages for social security purposes. A sounder interpretation of the legislative history of the Social Security

107. See text accompanying notes $89-92$ supra.

108. For discussion of the evolution of the convenience of the employer doctrine, see Commissioner v. Kowalski, 434 U.S. 77 (1977); Kragen \& Speer, supra note 89.

109. I.R.C. $\$ 119$.

110. $101 \mathrm{~S}$. Ct. at 2295 n. 13 . 
Act would define wages to include all benefits received from the einployment relationship. ${ }^{111}$ It reinains to be seen, however, what definition should be used for incoine tax withholding purposes. Part III of this Comment addresses that issue.

\section{III \\ THE SCOPE OF WithHOLDING FOR INCOME TAXES}

\section{A. Central Illinois' Definition of Wages}

Before analyzing the legislative history of the incoine tax withholding provisions, it will be useful to examine in greater detail the Supreme Court's holding in Central Illinois Public Service Co. v. United States. ${ }^{112}$ The issue there was whether the plaintiff employer should have withheld incoine taxes on amounts it paid as reimburseinents to einployees for lunches eaten while on company business. All parties agreed that the payinents fell outside the convenience of the einployer doctrine and represented income to the recipient employees. ${ }^{113}$

The court of appeals had required that taxes be withheld, noting that "[t]he einployment relationship is a two-sided bargain, with the employee's services being given for a total package of reinuneration, including salary, pension, paid vacation time and other remuneration such as reimbursed lunches." 114 Since the reimbursements were part of the package, they constituted wages subject to withholding. The court buttressed its holding by referring to the primary purpose of the withholding statute - collecting in advance inconie taxes that will coine due at the end of the tax year. ${ }^{115} \mathrm{~A}$ broad definition of wages, the court reasoned, would help effectuate the goal of current payinent.

The Supreine Court reversed. As shown in Part I, the Court was concerned with the possible retroactive effects of its decision. ${ }^{116}$ Instead of relying solely on the retroactivity rationale, ${ }^{117}$ however, the Court also concluded that Congress intended to exclude from the defimition of wages some fringe benefits on which income taxes would be due. Without denying the legislative intent to ensure current payment of ultimate income tax liability, the Court stressed that in enacting the income tax withholding scheine, Congress was very concerned with

111. As discussed in text accompanying note 139 infra, however, certain fringe benefits could be excluded from social security taxation when such exclusion would serve a specific policy goal.

112. 435 U.S. 21 (1978).

113. Id. at 24. This point had been settled by Commissioner v. Kowalski, 434 U.S. 77 (1977).

114. 540 F.2d 300, 302 (7th Cir. 1976), rev’d, 435 U.S. 21 (1978).

115. Id.

116. See text accompanying notes 26-28 supra.

117. This approach was taken by Justices Brennan and Powell in their concurring opinions. 435 U.S. at 33-38 (Brennan, J., concurring) and at 38-39 (Powell, J., concurring). 
" "the interest of simplicity and ease of administration." "118 The Court did not examine the legislative history to determine what simplicity and ease of administration meant to Congress or how Congress intended to serve those goals. The Court simply concluded on the basis of its own impressions that ease of administration would best be served by a narrow definition of wages. It rejected the court of appeals' "total package" theory, stating that withholding is "inuch narrower" than the scope of the incoine tax itself. ${ }^{119}$

\section{B. Legislative History}

A careful examination of the legislative history of the incoine tax withholding provisions shows that while Congress was concerned with ease of administration, the Central Illinois Court misunderstood the means Congress used to accomplish its objective. Congress intended to ensure ease of administration in two ways: by withholding taxes only on wages and not on bond interest and dividends, and by tracking the definition for wages that was already in use in the social security context.

The first way in which Congress sought to cut administrative costs was by limiting income tax withholding to wages. A comparison of the House and Senate versions of the first withholding provisions illustrates this fact. The 1942 revenue bill adopted by the House would have instituted a withholding systein for dividends and bond interest as well as wages. ${ }^{120}$ By the time the Senate Finance Committee held hearings on the bill, ${ }^{121}$ however, increased public awareness of the provisions in the House bill had generated much public reaction critical of withholding on bond interest and dividends. Witnesses in the Senate hearings argued that severe administrative problems would result due to the liuge number of recipients and the sinall size of inany of the payinents. ${ }^{122}$ Millions of additional withholding accounts would have had to be cre-

118. 435 U.S. at 27 (quoting S. ReP. No. 1631, 77th Cong., 2d Sess. 165 (1942)).

119. Id. at 29.

120. H.R. REP. No. 2333, 77th Cong., 2nd Sess. 125 (1942).

In passing this broad withholding scheme, the House was following the recommendations of Treasury Secretary Morgenthau, who had advocated withholding on "those incomes that are paid periodically, imcluding wages, salaries, bond interest, and dividends." Revenue Revision of 1942: Hearings Before the House Comm. on Ways and Means, 77th Cong., 2d Sess. 5 (1942) (statement of Henry Morgenthau, Jr., Secretary of the Treasury).

121. See Revenue Act of 1942: Hearings Before the Sen. Comm. on Finance, 77th Cong., 2d Sess. (1942).

122. For example, an official of a national association of savings and loan corporations testified that his organization alone paid dividends to 10 to 12 million recipients, all of whoun received only nominal amounts. He compared this number with the estimated total of 27 million wage earners in the country. Id. at 965 (statement of Morton Bodfish). A bank president pointed out that billious of bond coupons circulate throughout the country every year. Id. at 1995 (statement of Charles Mylander). 
ated at tremendous cost, and relatively little additional revenue would have been brought into the treasury.

The Senate Committee's response to such arguments was summed up in the committee report: "in the interest of simplicity and ease of administration," the Senate bill would limit withholding to "salaries, wages, and other forms of compensation for personal services." 123 The Conference Cominittee accepted the Senate withholding sclieme. ${ }^{124}$

The following year, the House Ways and Means Committee held hearimgs on income tax withholding provisions designed to replace those enacted im 1942. ${ }^{125}$ This time the Treasury Departinent advocated withholding only on wages and salaries, noting that this alone would reach seventy percent of all taxable income and citing administrative problems im withholding on the large number and small amounts of bond interest and dividends. ${ }^{126}$ Congress accepted the Treasury recommendation, agam limiting withholding to wages in the Current Tax Payment Act of 1943. ${ }^{127}$

The other ineans by which Congress intended to achieve ease of administration was by tracking the social security tax base as the general basis for withholding. ${ }^{128}$ By using this familiar standard, Congress eliminated the need for the Treasury to formulate an entirely new set of rules and regulations governing income tax withholding. In most cases, employers would be able to determine which items were subject to income tax withholding by reference to their established practices with respect to social security taxes. Employers would thus be faced with a reasonably unified tax system rather than two entirely imdependent ones.

The two categories of withholding could not be entirely symmetrical, lowever, because Congress had a much different purpose im adopting income tax withholding legislation than it lad when it adopted the social security tax provisions. It adopted income tax withholding to collect in advance the incoine taxes that einployees would owe at the end of the tax year. Of course, there would be hittle point in withholding taxes on benefits not subject to income tax, for the government would only have to repay those amounts at tax time. Thus, in enacting

123. S. REP. No. 1631, 77th Cong., 2d Sess. 165 (1942).

124. H.R. REP. No. 2586, 77th Cong., 2d Sess. 1 (1942) (Conference Committee Report).

125. Individual Income Tax: Hearings Before the House Comm. on Ways and Means, 78th Cong., 1st Sess. (1943).

126. Id. at 36 (statement of Randolph Paul, General Counsel for the Treasury Department).

127. See H.R. REP. No. 401, 78th Cong., 1st Sess. 21 (1943); S. REP. No. 221, 78th Cong., 1st Sess. 17 (1943); H.R. ReP. No. 510, 78th Cong., 1st Sess. 28 (1943) (Conference Committee Report).

128. This is illustrated by the fact that Congress used wages as the base for withholding of both social security and income taxes and defined wages in substantially the same language in the statutes. See text accompanying notes 12-22 supra. 
the Current Tax Payment Act, Congress clearly, although implicitly, excluded from withholding amounts tliat would ultimately not be subject to income taxation under doctrines like the convenience of the employer rule. ${ }^{129}$ As we saw in Part II, lowever, Congress liad a nucli different purpose in enacting social security taxes: it wanted to provide an insurance-type systein for protecting employees from the loss of employinent benefits due to old age or unemploynient. ${ }^{130}$ This Comment has previously argued that given this purpose and choice of funding metliods, it is reasonable to conclude that Congress intended all employment benefits to be subject to social security taxes. ${ }^{131}$ Thus, the different purposes of the incoine tax and social security withholding provisions create a slight asymmetry in the scope of wages under the two statutes.

Neither of Congress' methods for achieving administrative simplicity serves as a rationale for excluding taxable fringe benefits fron income tax withholding as was done in Central Illinois. The policy underlying Congress' decision limiting withholding to wages instead of also extending it to bond interest and dividends does not apply to fringe benefits. While withholding on bonds or dividends would liave entailed opening numerous new withholding accounts, withholding on fringe benefits would require no new accounts. Employers would already be withholding on employee salaries, so it would be a simple matter to withhold on all taxable fringe benefits as well. Likewise, 'Congress' decision to use the social security concept of wages as the general basis for income tax withholding would provide no rationale for excluding fringe benefits from incoine tax withholding. Indeed, if Congress intended in the social security context to tax all employnient benefits, the social security concept of wages would serve to nuandate withholding on all benefits. Of course, as just slown, some fringe benefits are properly excluded froin income tax withholding, but this is because they do not constitute inconie, not because they do not fall within the general social security definition of wages. In sum, in a case like Central Illinois, where all parties agree that the fringe benefits constitute taxable incoine, Congress' concerns for administrative simplicity do not justify an exclusion of benefits from income tax withholding, and the Supreine Court erred in so holding.

Indeed, excluding some taxable fringe benefits fron inconie tax

129. See the discussion of the legislative intent in Maine Note, supra note 6, at 405-06. Congress has followed this pattern consistently. For example, in 1969, when Congress passed statutory rules prescribing the income tax treatment of moving expenses, it carefully specified that the withholding treatment would correspond with the ultimate tax liability. Humble Oil \& Ref. Co.v. United States, 442 F.2d 1362, 1368-69 (Ct. Cl. 1971).

130. See text accompanying notes 71-81 supra.

131. See text accoinpanying notes $82-88$ supra. 
withholding may actually impede the administration of the tax system. First, the fact that the employer is not required to withhold taxes on some taxable fringe benefits increases the likehihood that mcome from such items will not be reported by employees and will therefore not be taxed. Second, excluding some taxable benefits while including others $^{132}$ creates uncertamty im the tax systein and engenders litigation. ${ }^{133}$ The simple rule that all taxable fringe benefits are wages subject to income tax withholding produces the system that is easiest to administer.

IV

\section{A Suggested APPROACH}

The foregomg analysis of the legislative history of the social security and income tax withholding provisions lays the groundwork for a very simple fringe benefit withholding rule to replace the judicial tests discussed in Part I. This Comment recommends that, with two qualifications, all fringe benefits should be subject to income tax and social security withholding requirements.

The first qualification is that fringe benefits that are not taxable under income tax doctrines such as the convemence of the employer rule would be excluded from income tax withholding. This qualification acknowledges the fact that Congress did not intend to withhold mcome taxes that would never be due. ${ }^{134}$ This exclusion would, of course, require that employers withhold social security taxes but not income taxes on soine fringe benefits. With modern busmess equipment, however, this should present no major difficulty. ${ }^{135}$ Indeed, minor differences in the method of computing social security and income tax withholding liabilities have always existed. For example, social security provisions set a maximum limit on an employce's total annual social security hability, ${ }^{136}$ although there is no upper limit on an individual's income tax liability. Similarly, while social security taxes apply a fixed percentage rate to all employees, ${ }^{137}$ income tax withholding is computed under progressive rates that vary between individuals de-

132. For example, despite Central Illinois, the Treasury regulations still require withholding on such fringe benefits as vacation allowances, Treas. Reg. $\$ 31.3401$ (a)-1(b)(3) (1957); pensions, id. at \$31.3401(a)-1(b)(1) (1957); and sick pay paid after Jan. 1, 1977, id. at \$31.3401(a)l(b)(8)(ii)(b) (1977).

133. See, e.g., cases cited in note 7 supra.

134. See text accompanying note 129 supra.

135. See text accompanying note 96 supra.

136. See Social Security Act of 1935, Pub. L. No. 74-271, $\S \S 210,811,49$ Stat. 639 (1935) (codified at I.R.C. $\$ \S 3306(b)(1), 3121(a)(1)$ ).

137. See I.R.C. $\$ \$ 3101,3111,3301$. 
pending on the individual's exemptions and projected gross income. ${ }^{138}$ In short, given the differences that already exist in the withholding schemes, the proposed exclusion would add little additional complexity.

The second qualification is that some fringe benefits might justifiably be entirely excluded from withholding because of extrinsic policy reasons. For example, the Treasury might conclude that certain types of benefits are too difficult to value and therefore exclude them by regulations. Or, it may be too difficult to keep track of which einployees actually receive certain benefits. Similarly, the Treasury could adopt a de minimis exception for certain kinds of benefits that are of so little value as not to justify the expense of withholding. ${ }^{139}$ Such exclusions would, of course, serve the goal of ease of administration.

\section{CONCLUSION}

In sum, the federal courts have thus far failed to develop a workable test for determining which fringe benefits constitute wages for the purposes of computing social security and income tax withholding. Moreover, when the Supreme Court excluded solne fringe benefits from social security withholding in Rowan and some taxable fringe benefits from income tax withholding in Central Illinois, it misread the legislative history of the withholding schemes. This Comment has examined that legislative history and has suggested a test for withholding on fringe benefits more faithful to congressional imtent. In the absence of specific policy reasons to the contrary, employers should be required to withhold social security taxes on all fringe benefits. The same rule should apply in the income tax context, subject to the caveat that fringe benefits that are not taxable as income should also be excluded from income tax withholding.

Peter W. Colby*

138. See I.R.C. $\$ 3402$.

139. See, e.g., Treas. Reg. § 31.3401(a)-1(b)(10) (1957); Rev. Rul. 59-58, 1959-1 C.B. 17.

* B.A. 1978, University of Virginia; J.D. 1981, Boalt Hall School of Law, University of California, Berkeley. 